\title{
Development Trends in Human Resource Management in Small and Medium Enterprises in the Visegrad Group
}

\author{
Ladislav Mura ${ }^{1}$, Aleksandr Ključnikov ${ }^{1}$, Manuela \\ Tvaronavičien $\dot{e}^{2}$, Armenia Androniceanu ${ }^{3}$
}

${ }^{1}$ Faculty of Economics and Business, Pan-European University in Bratislava, Tematínska 10, 851 05Bratislava, Slovakia, E-mail: ladislav.mura@paneurouni.com, kliuchnikov@gmail.com

${ }^{2}$ Faculty of Economics, Vilnius Gediminas Technical University, Sauletekio al. 11, 10223 Vilnius, Lithuania, E-mail: manuela.tvaronaviciene@vgtu.lt

${ }^{3}$ Faculty of Administration and Public Management, The Bucharest University of Economic Studies, Piata Romana 6, 010374 Bucharest, Romania, E-mail: armenia.androniceanu@man.ase.ro

\begin{abstract}
The processes of transformation and the changes in company structures that have been carried out in market economies have impact also on human resources management in all businesses. The objective of the paper is to highlight the current trends in human resources management and development in small and medium-sized enterprises in the countries of Visegrad Group. The research has been focused on a set of factors having impact on human resource management in enterprises operating in selected countries. The methodology is selected in line with the goals of the research. We have proved what macrofactors and to what extent have impact on human resources management. Our research has been focused on identifying current trends in the above mentioned field. Our concern has also been to present micro factors that have impact on making decisions by personnel managers. The key factors, corporate strategies and corporate policy in human resource management in small and medium enterprises are presented in the paper.
\end{abstract}

Keywords: human resource management; small and medium enterprises; development and trends in human resource management; Visegrad Group

\section{Introduction}

The current business environment is determined by a receding economic crisis that had interfered in all-sized businesses in a negative way. The environment can be identified also by a very strong competitiveness among businesses. The above 
mentioned facts have had impact on running business in all sectors of the national economy [1] and they have become key factors designing further development and prospects in business activities. Last decade some new tendencies in companies that follow the global current trends including challenges and business and financial risks are observed. They are all determinants that form the business environment [7], in which businesses and enterprises operate and determine the quality of the environment according to the size of the company and the type of its activities. Entrepreneurs start up their companies in accordance with the conditions created for running a business. Transformations in the external business environment have direct impact on the internal environment in companies and on the human resources, marketing, finance, information technologies, etc. The internal environment in companies can be adjusted and modified by company management to a certain extent, the external environment of companies must be accepted by them and companies need to be modified to it if they want to be successful in the market.

Slovakia as a member of the European Union shares the specifics of the EU business environment furthermore it has its national specifics [3] based on the size of the market, geography and development of regions. Other Visegrad countries have similar or identical conditions for business development. In lines with the statements by [12] competitiveness of national economies depends on competitiveness of enterprises, companies, competitiveness of regions [13] and socio-economic conditions [5]. Regional development [20] and development of countries can be conditioned by the results that companies achieve and then they result in economic growth [32]. Economic growth in each country is based on the relation between supply and demand. The relation enters company structures and defines further development and future prospects. Companies and enterprises can become competitive when they respond to customers' needs and market changes in a flexible way [23, 42]. Small and medium enterprises play a key-role in national economies and according to $[19,38]$ they are the most important element in economic development. The above mentioned statements underline the need to deal with the issue of entrepreneurship, of running a business and its conditions. Entrepreneurs take the risk and responsibility for their decisions and in small and medium enterprises making bad decisions may result in fatal consequences [34]. The determinants having impact on entrepreneurship are of different types, such as external and internal. Our paper focuses on one of the key determinants and it is human resources as a functioning area in company management. Intellectual capital born by human resources is considered by many authors [18] to be the most important. Human resources need to be led in such a way that they can become an effective capital for companies [29], producing new ideas, showing hard working effort and loyalty. The effectiveness is based on the attitude and qualities of managers and their ability to motivate and initiate human resources to achieve the company objectives. 


\section{Theoretical Background}

Nowadays human resources management in an entrepreneurial and business environment needs to be understood as a strategic attitude towards recruiting, selecting, hiring, and developing and training employees, labour force. Also, the authors [33] state that human resources play a strategic role and have a firm position in company strategic management.

It is a system of influencing people so that their activities can contribute to achieving partial goals of groups of workers, departments and achieving corporate goals that a company has set and are to be achieved. It is also an ability to persuade co-workers to attempt to achieve goals. Thus, leadership has become an inseparable part of management. Leadership relates to leading workers, being a leader and having charisma.

Table 1

Benchmarking: manager's and leader's tasks

\begin{tabular}{|c|c|}
\hline Managers & Leaders \\
\hline plan & Innovate current knowledge \\
\hline Maintain standard operations & $\begin{array}{c}\text { Develop approaches, relations with } \\
\text { markets }\end{array}$ \\
\hline Organize & $\begin{array}{c}\text { Inspire and motivate co-workers } \\
\text { Manage company's operation }\end{array}$ \\
$\begin{array}{c}\text { Find opportunities at new markets, } \\
\text { modifies products, carry out conceptual } \\
\text { activities }\end{array}$ \\
\hline Control & Creates values, resources \\
\hline Manage goals in a right way & Set up the right objectives (modify them) \\
\hline Ask a question: How? When? & Ask a question: What? And why? \\
\hline
\end{tabular}

Table No. 1 shows that managers fulfill challenging tasks so that by means of workers long-term, short-term, and operational and tactic plans can be fulfilled. Leaders have a task to be innovators [37], they are expected to develop standard attitudes to work in a creative way through motivating approaches. The activity must be connected to motivating people. According to the authors [44] motivation of employees and incentives are very necessary especially in a time of crisis and post-crisis period. The authors [25] focus their attention on analysing factors of motivation utilised by managers in company management. Their paper [16] deals with motivation factors applied especially by managers in small and medium enterprises. 
Human resources are employed also in knowledge management [8] not only in human resources management. Companies can profit on knowledge of their employees only when they create good conditions for transferring the knowledge into day-to-day practice [11].

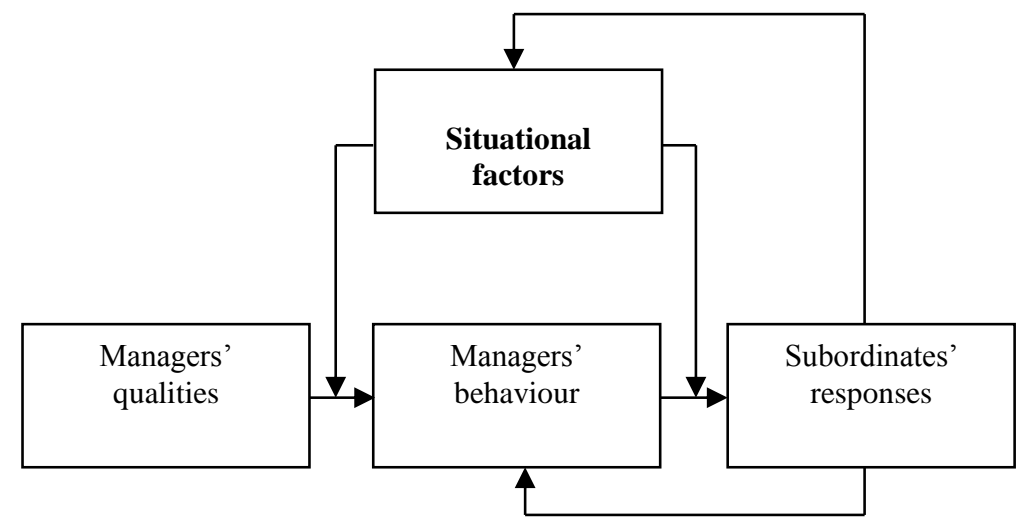

Figure 1

Integrated model of leading employees

Diversity in human resources management becomes more complicated as in practice managing employees needs to apply also psychological approaches emphasising interpersonal factors, as it is emphasised by [24]. Only in this way an effective system of managing employees [27] and a motivating working environment can be created by means of developing corporate culture and transparency [41, 26]. Symbiosis of managerial and psychological factors can initiate effective management. Many authors have devoted their specialised work to this field - leading employees. An integrated model of leading people is based on situational factors referring to managers' qualities and behaviour. They are shown in picture no. 1 .

The current labour market enables free active migration, movement of labour force, of employees in European countries [36]. The European human resources management can be characterised by outsourcing employed by small-sized companies, as it is described by the authors [9]. From the economic point of view outsourcing is economical and cutting cost in small-sized companies as some of specific operations may be carried out by external companies [40]. At the same time, full-time workers are needed to increase their productivity [28]. The authors [17] in their study highlight the current trends in human resources and are stating that human resources management cannot be done by chance, it must be target-oriented and conditioned by the market situation and by the company needs. Companies modify their conditions to the market changes that are reflected also in personnel management [15]. Since needs of companies that are affiliated with the company goals are diverse and relating to the production programme, seasonal factor and other factors, flexible forms of employment can be observed in the labour market 
[39]. The valid labour law enables such an option for companies [22]. Entrepreneurs as employers have been appealing on creating more flexible and liberalized labour law relations that may result in higher employment rate [43].

Current entrepreneurial activities can be evaluated as starting business in the national market and to some extent in the international market as well. Most European countries have accessed the European Union and are integrated so except for national legislation the EU countries have to observe and follow international regulations valid for the EU [4]. The impact of international environment on SMEs is inevitable. Regional development [14] is conditioned by regional economic growth and the quality of life in regions [10] and in the country.

Enterprises and businesses play a key role in each developed economy specified by competitiveness principles, diverse forms of ownership and competitiveness between companies of different size. The Private sector represented by small and medium enterprises produce more than ninety per cent of the GDP, its contribution in added value amounts to more than a half of the value created by companies and offers two thirds of the positions and ensures two thirds of the employment rate. Their existence cannot be replaced and is in line with the process of globalization. Many enterprises and businesses view the option for business internationalization as an opportunity to add a value to the company resources and to gain some achievements and success. Operations in a company in the international environment mean also to respond to changes in the company environment [2]. Managers have to focus attention on every company operation as the risk carried by companies in a tough international competition is much higher. Human resources management in an international environment means to perform managerial activity outside a country furthermore managers need to be prepared for their international operation. If they underestimate the preparation stage, they are usually unsuccessful.

The performance of companies in the international markets means to get to know the markets, their specifics and conditions. Referring to the diversity in cultures, jobs and economic conditions it is necessary to prepare each stage of human resources management [30] carefully, including recruitment [21], selection and modification and then establishing the right style of managing employees [31], ensuring a systemic development and training employees [35] and adapting to the conditions of a country or a market.

Many specialists have been paying close attention to the tendencies in development and management of human resources. Some of the specialists in their studies analyse human resources management in national companies and some of them analyse the issue in large international, global companies and corporations. A certain group of specialists carry out research in human resources management in small and medium - sized companies. This paper reflects the need for monitoring trends in the field of development of human resources management. We have paid attention to and searched HR management in Slovak companies and neighbouring countries forming the Visegrad Group. 


\section{Data and Research Methodology}

The methodology applied in the paper is based on the objectives we have set up for our research in HR management in Visegrad Group countries.

Our paper is aimed at current trends in human resources management and development in the sector of small and medium enterprises operating in the Visegrad Group. We have searched a group of factors having impact on human resources management in companies, in selected countries. The methods are selected in order to achieve the research goal. We have searched impact and its extent of a group of macro factors on HR management, so that current trends in management can be identified. Our interest covers also micro factors having impact on making decisions by HR managers. The paper presents the most challenging factors that have impact on HR management. It also presents strategies and policy applied in HR management in SMEs.

We have opted for the SME sector on purpose. According to current data small and medium enterprises have opened the largest number of positions; they absorb free labour force, bring a large number of innovations and form the backbone of the economy in the countries of the Visegrad Group and in the EU. The enterprises represent ninety-nine per cent of all companies operating and they are a driving force for economic growth.

We have gathered facts offered by primary and secondary resources on the above mentioned issue. Primary facts represent results gained in a research carried out at the Pan-European University, the Faculty of Economics and Business in Bratislava collaborating with institutions operating abroad. Primary data are gained during the research through a questionnaire processed during the years 2013 until 2016. The questionnaire was distributed to SMEs in Slovakia, the Czech Republic, Hungary and Poland. The research started with a pilot research carried out with a small number of companies. All small and medium-sized enterprises represent the basic statistics files. We have selected a file via stratified selection ad hog and it is based on selected indicators at a macro-level. Companies selected and appointed for our research sample needed to meet following criteria:

- $\quad$ They operate in Visegrad Group countries: in Slovakia, the Czech Republic, Hungary and Poland;

They meet the condition for being a SME according to the categorization described in the EU Regulation No.2003/361 ES dated on May 6, 2013;

- $\quad$ They have revealed their interest and a will to participate in the research.

The selected statistics file is created by the data on 1248 businesses categorised as SME operating in Visegrad countries. For our research also, secondary resources were needed and they are represented by literature written by national and international authors - specialists in management, HR management and business 
activities. The information offered by other authors has been uploaded from an international scientific database and mirrors the current trends in the researched area

Adequate scientific methods have been applied to cover all the parts of the research and to analyse and interpret the results. Hypothesis have been defined and statistically tested. The chi-squared Test of Independence has been employed in dependence verification. Pearson's Correlation Coefficient $\mathrm{C}$ has been applied while testing the strength of dependencies. In addition to those, methods of descriptive statistics and logics learning methods have been employed

Chi-squared test of independence is mathematically reported:

$$
\chi^{2}=\sum_{i=1}^{k} \sum_{j=1}^{l} \frac{n\left(n_{i j}\right)^{2}}{n_{i} n_{j}}-n
$$

$\mathrm{H}_{\mathrm{o}}$ : line and column variables are not dependable

$\mathrm{H}_{1}$ : line and column variables are dependable

Calculated test criterion $\chi^{2}$ (Chi-squared) to verify the null hypothesis is compared to the table value or P-value is compared to the selected significance level. Selecting a significance level for testing criterion is $5 \%$. Testing criterion to verify the null hypothesis $\mathrm{H}_{0}$ assuming independence between given qualitative signs is calculated according to the relation:

$$
\chi^{2}=\sum_{i=1}^{r} \sum_{j=1}^{c} \frac{\left(E_{i j}-T_{i j}\right)^{2}}{T_{i j}}
$$

$\mathrm{H}_{\mathrm{o}}$ is accepted, if the calculated value of the testing criterion $\chi^{2}<\chi^{2}$ tab. If $\chi^{2}$ $>\chi 2$ tab the Hypothesis $\mathrm{H}_{\mathrm{o}}$ is rejected, it means the signs at the selected significance level are dependent. Based on P-value the Null Hypothesis $\mathrm{H}_{\mathrm{o}}$ is expressed in the following way:

$>\mathrm{P}$ - value $<\alpha=0.05$ statistically proven dependence

$>\mathrm{P}$ - value $<\alpha=0.01$ statistically highly dependent proven

$>\mathrm{P}$ - value $<\alpha=0.001$ statistically highly dependent proven

Pearson correlation coefficient $\mathrm{C}$ is applied while testing the strength of dependence between qualitative signs and is defined by the relationship:

$$
C=\sqrt{\frac{\chi^{2}}{n+\chi^{2}}}
$$




\section{Results and Discussion}

Businesses and enterprises being oppressed by hard competitiveness have been trying to find new markets where they could be able to sell the company's resources and make a better profit. Therefore, many of them do not operate in the national domestic environment, but they make their business international and enter into foreign markets based not far off. At present, not only SMEs enter international markets but also companies running micro business and small enterprises make their business international. It can be said that the European Union businesses have become international; they do not run their business operations only in the country.

Companie's management needs to realise that being active in an international environment means to adopt the process of managing into the international business environment and to the culture having an impact on operation of businesses. Macro factors concerning legislation, politics, culture, geography, demography, ecology and others must be taken into account by company management. There are also other micro factors affiliated with real businesses and they are owners, managers and employees. In addition to them, there is also life cycle of the business, quality of technology, knowledge, and the financial situation of the company, etc.

Monitoring current trends in the business development belongs to the basic tasks of company management and must be involved in operational and strategic management. Based on the data it is possible to accept effective measures so that the development in a certain area can be corrected and modified. There are a large number of diverse factors that have impact on management. We have decided to opt especially for human resources management as human resources are considered to be the basic resource in a company; without them, companies would not be able to perform a single activity.

Next part of our paper analysis primary data gained from companies in a time of research projects. It is a general fact, that most often companies enter the markets in neighbouring countries and this is the reason to analyse the data offered by companies operating in Central Europe, in the Visegrad Group Countries (Slovakia, Czechs, Poland, and Hungary).

The basic data were gained via surveys designed for the purpose to get and specify current trends in development of human resources management in small and medium enterprises in the Visegrad Group. The survey was tested during a pilot study of our research, then some corrections were implemented and when we received the feedback from companies the scientific research started on a larger scale. The data were gained through partnership research institutions.

Following table (Table 2) shows the number of companies taking part in a primary research in the countries during the research. 
Table 2

Companies and countries participating in the research

\begin{tabular}{|c|c|c|}
\hline Country & $\begin{array}{c}\text { Absolute number - } \\
\text { frequency (companies) }\end{array}$ & Relative number in \% \\
\hline Slovakia & 320 & 25,64 \\
\hline Czech Republic & 356 & 28,53 \\
\hline Poland & 298 & 23,88 \\
\hline Hungary & 274 & 21,95 \\
\hline Total & $\mathbf{1 2 4 8}$ & $\mathbf{1 0 0}$ \\
\hline
\end{tabular}

A total of 1,248 companies - SMEs were selected out of the basic statistics data sets. Table 1 shows countries participating in the research: 320 Slovak companies represent more than one fourth of respondents. The Czech Republic is represented by 356 companies, that is more than $28 \%, 298$ Polish companies formed almost $24 \%$ of respondents, the least number of companies represented Hungary -274 companies, almost $22 \%$ of respondents.

Figure 2 illustrates the size of companies divided into categories per countries. The largest number of micro-companies was of Polish origin and from the Czech Republic. The smallest number of companies in this category operated in Slovakia. The largest group of small enterprises operated in Slovakia, followed by the Czechs. Quite large number of small enterprises participating in the research was from Hungary. Middle sized companies are represented by the largest number of Czech and Slovak companies. The smallest number of companies in this category was Polish enterprises.

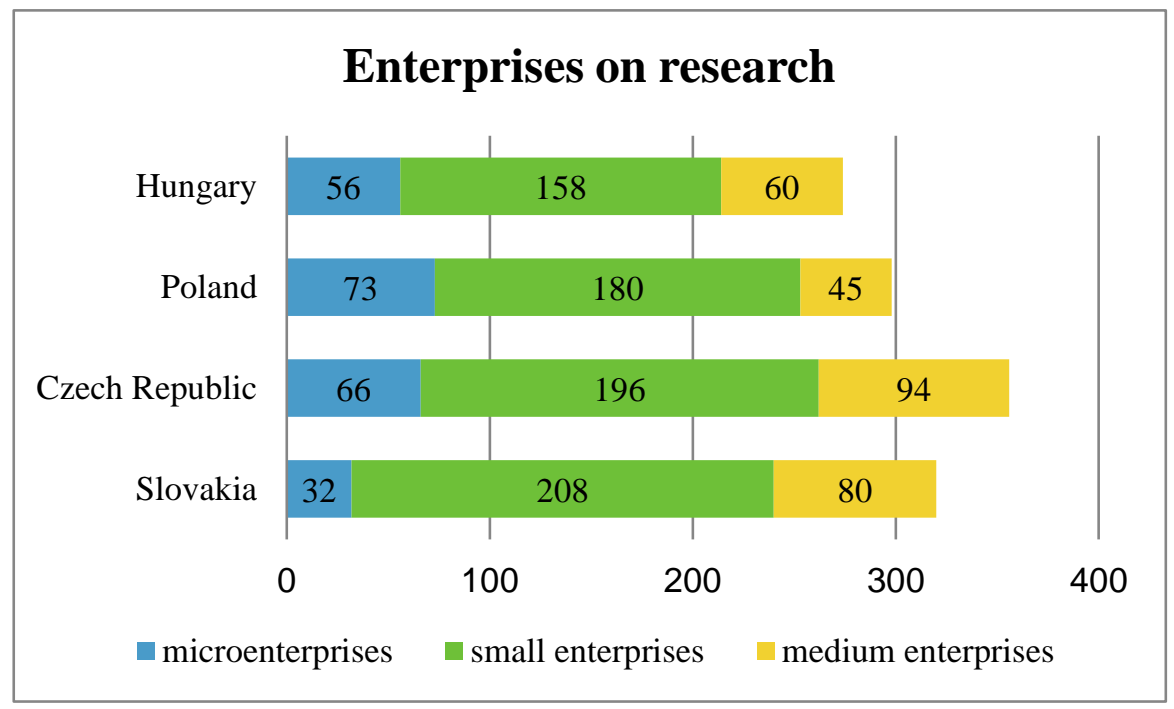

Figure 2

Enterprises on research 
The research carried out in companies operating in the Visegrad Group countries covers a total of 1,248 companies employing 22,747 workers totally. This data is important from the point of view of HR management. The HR management and the attitudes of managers towards it are different in companies and depend on the number of employees. Figure 3 shows the number of employees categorized according to the size of the company. The least number of employees are employed by micro-companies defined by the number 0 to 9 employees. Our sample of companies contains companies employing above 160 workers (Slovakia) up to 362 employees (Czechs). From the point of view of employment an interesting fact is found in the category of small enterprises; the number of employees in the enterprises amounts to more than 4,000; in Slovakia it was 4,190 and in the Czech Republic it amounted to 4,704. The least number of employees: 3,002 in the category of small enterprises was employed by the Hungarian companies that participated in our research. It is a surprising finding as the largest category of middle-sized companies had the number of employees within the limits from 3,690 in Poland up to 7,208 in the Czech Republic. The Polish category of small enterprises employed more workers than the category of middle-sized companies. In Hungarian middle-sized enterprises the number of employees varied and reached the number of employees in small enterprises in other countries.

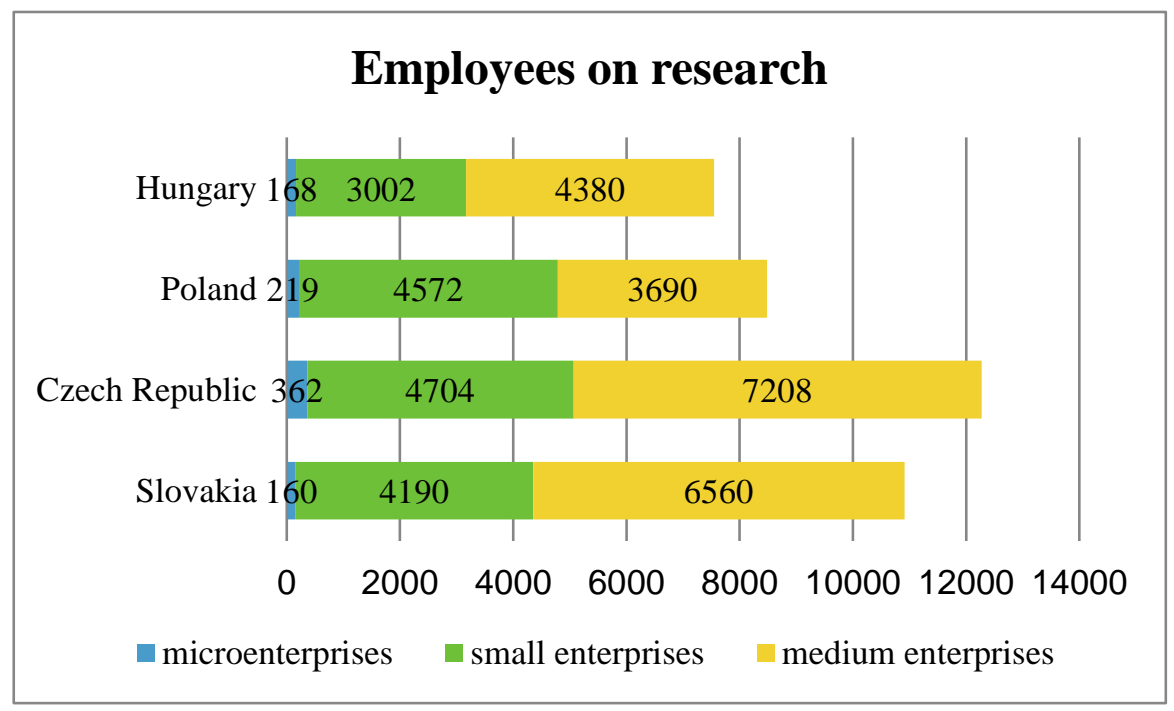

Figure 3

Employees on research

Following part of our paper analyses the attitude towards HR management in small and middle-sized enterprises in the Visegrad Group. We were interested also in factors having the largest impact on decision making in the field of human resources. The set of factors having impact on management can be divided into groups according to the type of factors from a macro level or into a group of factors 
belonging to the internal environment of a company (micro factors). At this point it is necessary to point out that the type of tools and measurements employed in human resources management depend on the fact of whether companies operate only at a national or international market or make the company activities international. When companies enter the global market they and their managers are confronted by specific conditions in the international business environment. It is a concern for the conditions of a hosting country in the field of legislation valid for businesses (in our analyses the focus is on labour law valid in a country concerned), furthermore a concern of the culture is also important (the issues of gender, working time, observing customs), demography, language competence of managers and employees involved in that working environment.

According to the above mentioned facts human resources managers modify their performance. Current trends in HR management approaches are based on the socalled Perlmutter's typology. The Perlmutter's international business model includes three dimensions with four managers' approaches towards HR management:

- Ethnocentric approach,

- Polycentric approach,

- Geocentric approach,

- Regiocentric approach (region-based approach).

The countries lying in Central Europe have applied regiocentric approach towards human resources management. Company managers while applying the regiocentric approach recruit and hire qualified candidates who know well the regional conditions and know well also the factors influencing the regional market. Employees work in a neighbouring market and get know the culture typical for the regional market. It means that the Visegrad Group countries and companies operating in them share identical markets and almost identical cultures.

We were inquiring which approach towards human resources management is applied by company managers most often. The findings are offered in figure 4 . We have verified the fact for size categories separately; results are for the complete set of companies. In the category of micro enterprises the prevailing approach towards HR management is an ethnocentric approach, $67 \%$ of companies apply the style of management in which managers and other employees are recruited and selected and appointed by the central company management. Owners and top managers trust "their people" and they are identified by a mutual trust. Regiocentric approach is applied in almost one fourth of management approaches (23\%). Micro enterprises out of all enterprises and businesses are the most sensitive to changes and are most vulnerable. Due to this reason managers in micro enterprises apply the regiocentric approach, as employees get know well the conditions in regional markets. This is a way how companies can avoid the risk they bear when they do not know the conditions in the business environment. Geocentric approach is applied only by $8 \%$ 
of micro enterprises. This category of enterprises is very small to recruit best qualified employees from other regions and to motivate them. Almost $2 \%$ of micro enterprises apply the polycentric approach towards human resources management. The HR managers inquired in our survey report the lack of active communication and loss of the employees' performance control as the most outstanding drawback.

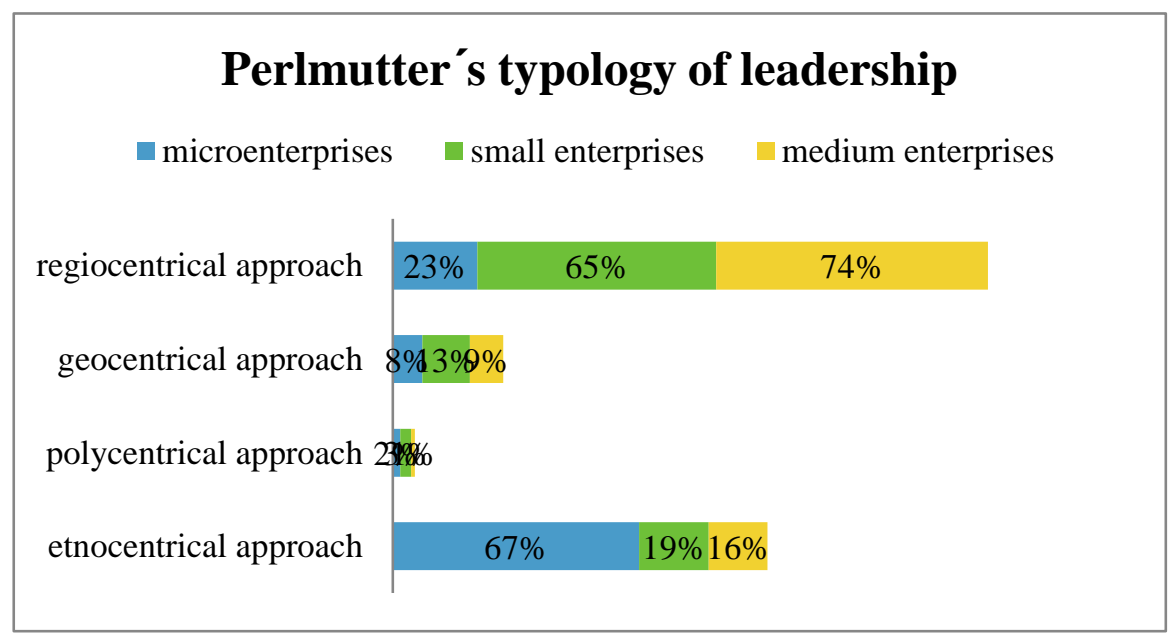

Figure 4

Employees on research

The situation in the category of small enterprises is different. The region-centric approach is prevailing due to its advantage of knowing the region where the company runs its businesses. This approach is employed by $65 \%$ of respondents. The second position is taken by the ethnocentric approach that is preferred due to a complete confidence in teams. In small enterprises the geocentric approach is the third one applied by $13 \%$ of businesses. These businesses are a bit larger than micro enterprises so they can afford to employ qualified and trained candidates, human resources coming out of the region where the company is based. The businesses can offer better incentives and know-how than micro enterprises can. The polycentric approach is applied by small businesses the least. The reasons are identical to the ones in microenterprises.

The situation in the category of middle-sized enterprises is more outstanding for the approach preferred. Three fourths of inquired businesses - respondents have stated that they apply the regio-centric approach so that the risk can be minimized and the regional business environment is well known. The businesses belonging to this category slowly releases the ethnocentric approach. The confidence to other members of a team except to the company top management becomes stronger. The geocentric approach is applied by $9 \%$ of businesses inquired by our questionnaire. The indicator is smaller than the one in the category of small businesses. Relating to the size of companies and the time of running a business, middle-sized companies 
have already built a stable team of highly qualified workers. Polycentric approach has been applied the least, the percentage of inquired respondents amounts to almost $1 \%$.

A hypothesis has been tested whether the experience gained by managers in the field of human resources management may be reflected in the business success of companies.

$\mathrm{H}_{0}$ : Business success and the managers experience gained in managing human resources are independent variables.

$\mathrm{H}_{1}$ : Business success and the managers experience gained in managing human resources are dependent variable.

The hypothesis has been tested at the significance level $\alpha=0.05$.

Based on the results of the test the hypothesis $\mathrm{H}_{0}$ is rejected, according to it there is no dependence between business success and experience of managers gained while managing employees. Businesses involved in the research sample have reported better results in business success while appointing HR managers who have already gained experience with managing human resources. Table 3 shows the results gained in the test statistics.

Table 3

Hypothesis Verification - results

\begin{tabular}{|c|c|c|c|c|c|}
\hline & Value & Df & p-value & $\begin{array}{c}\text { Exact Sig. } \\
\text { (2-sized) }\end{array}$ & $\begin{array}{c}\text { Exact Sign. } \\
\text { (1-sized) }\end{array}$ \\
\hline$\chi^{2}$ & 4.887 & 1 & 0.042 & & \\
\hline Fisher's Test & & & & 0.428 & 0.428 \\
\hline
\end{tabular}

Verifying results of Chi-squared test also Fisher's test was employed. The interpretation by means of $\mathrm{p}$-value is identical to Chi-squared test.

Factors that have impact on human resources management are evaluated and the results are shown in Table 4. Six factors are selected and they are as it follows: planning, recruiting, hiring, mentoring, corporate culture and relations in a workplace.

Human resources planning as a part of HR management amounts the variable 5.64, while the median varies around the level 3.00. While testing the dependence strength the result is 0.38 and indicates the medium dependence. Recruitment amounts average value 7.32, median varies around the level 5.00 and while testing dependence strength a strong factor $(0.88)$ is concerned and has impact on effective human resources management. Thus, it can be said that businesses are motivated to hire qualified employees. The process of acquisition of employees amounts to an average value of 4.10, median - level 2 and Pearson's coefficient reaches the value of 0.26 . In running a business, a company means that there is a weak dependence and acquisition and recruiting employees does not represent a domain in personnel 
management in micro, small and medium-sized enterprises. Mentoring as a part of personnel management amounts an average value of 4.82, median reaches level 2 and middle dependence strength reaches the level 0.64. Corporate culture amounts to the average of 5.46, median - 3.00. Based on the result of Pearson's coefficient it can be concluded that personnel management reaches a middle dependence strength in the corporate culture. It is mirrored in practices of businesses that more and more companies are aware of the fact that corporate culture plays a key role in effective management. Relations in a workplace as one of the challenging factors reaches an average value of 5.14, median -2.00 and there is a middle dependence strength in relation to human resources. Prosperous relations at a workplace are a desired condition for the corporate culture and more and more companies are aware of this fact.

Table 4

Evaluation of Human Resource Management Factor's

\begin{tabular}{|l|c|c|c|}
\hline & Average & Median & Pearson's C \\
\hline Planning of Human Resources & 5.64 & 3.00 & 0.38 \\
\hline Recruitment & 7.32 & 5.00 & 0.88 \\
\hline Acquisition & 4.10 & 2.00 & 0.26 \\
\hline Mentoring & 4.82 & 2.00 & 0.64 \\
\hline Firm's culture & 5.46 & 3.00 & 0.52 \\
\hline Labor relations & 5.14 & 2.00 & 0.44 \\
\hline
\end{tabular}

\section{Conclusions}

Developed market economy is based on operations of small and middle-sized companies. They are flexible and able to adapt to changes at markets, although they are vulnerable at the same time. Due to this reason close attention is paid to them by national governments and by the EU as well.

The paper has searched current trends in HR management especially in the Visegrad Group countries. A primary research has been carried out in small and middle-sized enterprises including also micro, small and middle businesses. 1,248 businesses form the research sample.

It can be concluded:

- $\quad$ Micro businesses employ the least number of employees; employment in small enterprises in some countries can be compared to the employment in middlesized enterprises.

- Validity of Perlmutter's business model has been verified. The Visegrad Group countries apply the region centric approach towards human resources management. Its advantage is knowing the regional conditions and hiring employees who are fully aware of the regional facts and are qualified. The exception is micro businesses with prevailing ethnocentric approach. 
- $\quad$ A hypothesis has been tested: experience gained by managers in personnel management may be reflected in business success. The hypothesis is proved; it means that the experience in personnel management is mirrored in business success.

- $\quad$ The factors playing a key role in human resources management are: recruitment, planning, corporate culture and prosperous relations at a workplace.

From the point of view of development of human resources management in small and middle-sized enterprises it can be recommended that businesses need to concentrate on a specialised selection of employees, recruiting qualified and experienced workers who will become a competitive advantage. One more recommendation: more attention should be paid to mentoring employees who can become highly qualified and trained and loyal.

\section{Acknowledgement}

This paper was supported by the Grant Agency of the Ministry of Education, Science, and Research of Slovak Republic Project KEGA No.001UCM-4/2016 and project of GAAA Internationalization of family businesses: theoretical background - practical implications.

\section{References}

[1] Adamišin, P., Kotulič, R. Evaluation of the agrarian businesses results according to their legal form. Agricultural Economics-Zemedelska Ekonomika, Vol. 59, No. 9 (2013) 396-402

[2] Androniceanu, A. Good democratic governance based on a new model, Administratie si Management Public, Vol. 24 (2015) 56-63

[3] Bánociová, A., Raisová, M. Issues of Slovak Business Environment. Procedia Economics and Finance, Vol. 3 (2012) 1223-1228

[4] Becerra-Alonso, D., Androniceanu, A., Georgescu, I. Sensitivity and vulnerability of European countries in time of crisis based on a new approach to data clustering and curvilinear analysis. Administratie si Management Public, Vol. 27 (2016) 46-61

[5] Bednáriková, J., Stehlíková, B. The impact of the selected socioeconomic factors on the international migration in EU. $6^{\text {th }}$ International Days of Statistics and Economics (2012) 93-103

[6] Belás, J., Sopková, G. A Model of Entrepreneurial Orientation. Transformation in Business \& Economics, Vol. 15, No 2B (38B) (2016a) 630-645

[7] Belás, J., Sopková, G. Significant determinants of the competitive environment for SMEs in the context of financial and credit risks. Journal of International Studies, Vol. 9, No. 2 (2016b) 139-149 
[8] Bencsik, A., Juhasz, T. Knowledge Management Strategy as a Chance of Small and Medium-Sized Enterprises. International Business Strategy and Entrepreneurship: an Information Technology Perspective Book Series: Advances in Business Strategy and Competitive Advantage (ABSCA) Book Series (2014) 52-81

[9] Berber, N., Slavic, A. Human Resource (HR) Outsourcing in European Compensation Management in the Light of CRANET Research. Acta Polytechnica Hungarica, Vol. 13, No. 3 (2016) 207-225

[10] Bilevičienè, T., Bilevičiūte, E., Drakšas, R. Employment as a Factor of Life Quality. Journal of International Studies, Vol. 9, No. 3 (2016) 203-216

[11] Dobrai, K., Farkas, F., Karoliny, Z., Poor, J. Knowledge Transfer in Multinational Companies - Evidence from Hungary. Acta Polytechnica Hungarica, Vol. 9, No. 3 (2012) 149-161

[12] Dudáš, T. Methodical background of global indices of national competitiveness. International relations 2013: Contemporary Issues of World Economicsand Politics, Vols 1-4 (2013) 192-201

[13] Gavurova, B., Vagasova, T., Kovac, V. Competitiveness Assessment of Slovak Republic Regions. European Financial System 2016: Proceedingsofthe $13^{\text {th }}$ International Scientific Conference (2016) 175-+

[14] Havierniková, K., Srovnalíková, P., Janský, B. Identification of clusters' potential in regions. Actual Problems of Economics, 2015, Vol. 169, No. 7 , (2015) 236-244

[15] Jeřábek, Z., Čapošová, E. Institutional changes and qualification requirements of a company. Polish Journal of Management Studies, 2016, Vol. 14, No. 2 (2016) 93-103

[16] Karácsony, P., Machová, R. Comparison of the Employee Motivational Tools in Industrial Companies. CERS 2014: $5^{\text {th }}$ Central European Conferencein Regional Science, International Conference Proceedings (2015) 346-350

[17] Kazlauskaite, R. Buciuniene, I., Poor, J., Karoliny, Z., Alas, R., Kohont, A., Szlavicz, A. Human Resource Management in the Central and Eastern European Region. Global Trends in Human Resource Management (2013) 103-121

[18] Kijek, T. Intellectual Property Rights and Appropriability of Innovation Capital: Evidence from Polish Manufacturing Firms. Equilibrium. Quarterly Journal of Economics and Economic Policy, Vol. 11, No. 2 (2016) 387-399

[19] Ključnikov, A. Uncover SMEs finance through the impact of the specific factors. Evidence from Slovakia. Transformations in Business \& Economics, Vol. 15, 2B (2016) 741-754 
[20] Kordoš, M. Knowledge Economy Development in Global Economy Environment. $20162^{\text {nd }}$ International Conferenceon Educationand Management Science (ICEMS 2016) (2016) 142-146

[21] Krajňáková, E. Recruitmentof expertsincreativeindustry. Znalosti pro trzni praxi 2015: Zeny- Podnikatelky v minulosti a soucasnosti (2015)447-453

[22] Krošlák, D., Olšovská, A. Whistleblowing in the Slovak labor law regulation. Juridical Tribune-Tribuna Juridica, Vol. 5, No. 2 (2015) 7-24

[23] Kubak, M., Bosakova, L., Fisar, M., Hajduova, Z., Timurova, E. Dependence of Unemployment Change on Selected Economic Factors: Panel Data Evidence. Proceedingsofthe $19^{\text {th }}$ International Conference: Current Trends in Public Sector Research (2015) 21-28

[24] Lazányi, K. Who do You Trust? - Safety Aspect of Interpersonal Trust among Young Adults with Work Experience, 2016 IEEE $11^{\text {th }}$ International Symposiumon applied Computational Intelligence and Informatics (SACI) (2016) 349-353

[25] Lorincova, S., Hitka, M., Cambal, M., Szabo, P., Javorcikova, J. Motivational Factors Influencing Senior Managers in the Forestry and Wood-Processing Sector in Slovakia. Bioresources, Vol. 11, No. 4 (2016) 10339-10348

[26] Majerová, J., Križanová, A. Measurement of CSR performance - a necessary condition for effective corporate financial management. In Financial Management of Firms and Financial Institutions: $10^{\text {th }}$ International Scientific Conference, PTS I-IV (2015) pp. 725-732

[27] Merkevičius, J., Davidavičiené, V., Raudeliuniené, J., Buleca, J. Virtual organization: Specifics of creation of personnel management system. E \& M: Ekonomie a Management, Vol. 18, No. 4 (2015) 200-211

[28] Micallef, B. Determinants of Labour Productivity in Malta: Evidence from a Firm-Level Survey. Economics \& Sociology, Vol. 9, No. 4 (2016) 27-40

[29] Michalski, G. Effective Working Capital Investment - German Firms Case. Proceedings ofthe International Conference Quantitative Methodsin Economics Multiple Criteria Decision Making XVII (2014) 176-181

[30] Moravcikova, K., Lancaric, D., Ubreziova, I., Savov, R., Kozakova, J.Is Human Resources Planning Influenced by Foreign Ownership? Evidence from the Slovak Republic. Proceedingsof the $2^{\text {nd }}$ International Conferenceon European Integration 2014 (ICEI 2014) (2014) 492-498

[31] Profiroiu, A. G., Nastacă, C. C. 2016. The gender influence on leadership style practiced in the Romanian Government's working apparatus (Office). Administration and Public Management Review, No. 27 (2016) 74-93

[32] Raisová, M., Ďurčová, J. Economic growth-supply and demand perspective. Procedia Economics and Finance, Vol. 15 (2014) 184-191 
[33] Rajnoha, R., Lesníková, P. Strategic Performance Management System and Corporate Sustainability Concept - Specific Parametres in Slovak Enterprises. Journal of Competitiveness, Vol. 8, No. 3 (2016) 107-154

[34] Sobeková-Májková, M., Solik, J., Sipko, J. Problems with financing of SMEs as one of the business risks in the conditions of Slovakia. Finance and performance of firms in science, education and practice (2015) 1374-1389

[35] Spisakova Dulova, E., Gontkovicova, B., Hajduova, Z. Education from the perspective of the Europe 2020 strategy: thecaseofsoutherncountriesofthe European Union. Economics \& Sociology, Vol. 9, No. 2 (2016) 266-278

[36] Szczebiot-Knoblauch, L., Kisiel, R. Labour Supply in the Labour Market in Rural Areas in Poland. Oeconomia Copernicana, Vol. 5, No. 1 (2014) 97115

[37] Šimo, D., Mura, L. Manažment organizácií. Bratislava: Wolters Kluwer (2015) 264 p.

[38] Š́bertová, E. The activities of Slovak entrepreneurships in SMEs and their actuall practice problemes. Aktualne problemy podnikovej sfery (2012) 532538

[39] Švec, M. Bridget Jones - the social risks of flexible forms of employment. Multidisciplinary International Conference on Law within the Fine Arts and Fine Arts within the Law. Pravo v umeniaumeni v pravu (2011) 242-248

[40] Tušan, R., Bánociová, A., Buleca, J. Comparison of IFRS and Slovak Accounting Regulations in the Area of Accounting and Recognition of Noncurrent Assets. In Confronting Contemporary Business Challenges through Management Innovation (2013) 2376-2391

[41] Vetráková, M., Smerek, L. Diagnosing Organizational Culture in National and Intercultural Context. E \& M Ekonomie a Management, Vol. 19, No. 1 (2016) 62-73

[42] Vojtovič, S. The Impact of The Structural Funds on Competitiveness of Small and Medium-Sized Enterprises. Journal of Competitiveness, Vol. 8, No. 4 (2016) 30-45

[43] Zaušková, A., Madleňák, A., Švec, M. Legal Aspectsof Corporate Social Responsibilityin Conditionsof the European Unionandthe Slovak Republic. International Scientific Conferenceon Marketing Identity: Design that Sells (2013) 437-452

[44] Závadský, J., Hitka, M., Potkány, M. Changes of employee motivation of slovak enterprises due to global economic crisis. E \& M Ekonomie a Management, Vol. 18, No. 1 (2015) 56-66 